\title{
Toxicity, Deficiency and Dysmetabolism of Trace Elements in Ghanaian Clinically Stable Schizophrenics
}

\author{
George A. Asare*, Ruth Tetteh, Elsie Amedonu, Bernice Asiedu, Derek Doku \\ University of Ghana School of Allied Health Sciences (SAHS), PO Box KB 143, Korle Bu, Ghana
}

\begin{abstract}
Citation: Asare GA, Tetteh R, Amedonu $\mathrm{E}$ Asiedu B, Doku D. Toxicity, Deficiency and Dysmetabolism of Trace Elements in Ghanaian Clinically Stable Schizophrenics. OA Maced Med Sci. 2014 Jun 15; 2(2):293-298 http://dx.doi.org/10.3889/oamjms.2014.049 Key words: schizophrenia; trace elements; dysmetabolism; psychiatric patients; Accra.

"Correspondence: Dr. George A. Asare, Chemical Pathology Unit, Department of Medical Laboratory Sciences, School of Allied Health Sciences, College of Health Sciences, University of Ghana, P.O. Box KB 143, Korlebu, Accra, Ghana. Telephone: +233244627 456. E-mail: gasare@chs.edu.gh

Received: 06-Jan-2014; Revised: 24-Mar2014; Accepted: 08-Apr-2014; Online first: 12-Jun-2014

Copyright: ๑ 2014 Asare et al. This is an open access article distributed under the terms of the Creative Commons Attribution License, which permits unrestricted use, distribution, and reproduction in any medium, provided the original author and source are credited.

Competing Interests: The authors have declared that no competing interests exist.
\end{abstract}

\begin{abstract}
AIM: The purpose of the study was to determine the levels of Copper ( $\mathrm{Cu}$ ), selenium (Se), Zinc $(\mathrm{Zn})$, Lead $(\mathrm{Pb})$ and Lithium $(\mathrm{Li})$ in patients in Accra and Pantang Psychiatric Hospitals in Ghana since no data exist.

SUBJECTS AND METHODS: Simple random sampling of age-matched subjects was used to recruit 81 schizophrenics and 25 mentally healthy controls in 2012. Serum levels of $\mathrm{Cu}, \mathrm{Se}, \mathrm{Zn}, \mathrm{Pb}$ and $\mathrm{Li}$ were determined by flame atomic absorption spectroscopy (FAAS).

RESULTS: Mean levels were as follows: $\mathrm{Cu}_{\mathrm{t}} 766 \pm 250 \mu \mathrm{g} / \mathrm{L}$ and $\mathrm{Cu}_{\mathrm{c}} 855 \pm 270 \mu \mathrm{g} / \mathrm{L}(\mathrm{p}=0.168)$. $\mathrm{Se}_{\mathrm{t}} 149 \pm 72 \mu \mathrm{g} / \mathrm{L}$ and $\mathrm{Se}_{\mathrm{c}} 108 \pm 61 \mu \mathrm{g} / \mathrm{L}(\mathrm{p}=0.009) . \mathrm{Zn}_{\mathrm{t}} 702 \pm 438 \mu \mathrm{g} / \mathrm{L}$ and $Z \mathrm{n}_{\mathrm{c}} 1007 \pm 593 \mu \mathrm{g} / \mathrm{L}(\mathrm{p}$ $=0.028)$. $P b_{t} 1.38 \pm 0.05 \mu \mathrm{g} / \mathrm{L}$ and $\mathrm{Pb}_{\mathrm{c}} 0.10 \pm 0.05 \mu \mathrm{g} / \mathrm{L}(\mathrm{p}=0.000)$. Li levels for the test group $\left(\mathrm{Li}_{\mathrm{t}}\right)$ was $4077 \pm 2567 \mu \mathrm{g} / \mathrm{L}$, whiles that of the controls was undetectable $<0.02 \mu \mathrm{g} / \mathrm{L}$. Se, $\mathrm{Pb}$ and $\mathrm{Li}$ levels were significantly higher in schizophrenic patients compared to controls. While $\mathrm{Zn}$ and $\mathrm{Cu}$ levels were lower in the same group.
\end{abstract}

CONCLUSION: Trace elements dysmetabolism exist among Ghanaian schizophrenics and monitoring is essential to avoid the adverse effects of metal overload or deficiency.

\section{Introduction}

In 2001, 450 million people worldwide suffered from some form of mental disorder or brain condition [1]. Of the 21.6 million people living in Ghana, 650,000 were reported suffering from severe mental disorders and a further 2,166,000 from moderate to mild mental disorders in 2007 (WHO, 2007) [2]. Globally, the most frequent disorders are schizophrenia, anxiety disorders, depression, somatoform and substance abuse disorders [3].

Traditional prevalence or "core," is studiesgenerated estimates based on the population residing within a defined catchment [4]. The prevalence estimates would therefore differ within lifetime, period, and point prevalence [4, 5]. Furthermore, in developing countries the proportion of cases with acute onset schizophrenia was twice as high as in developed countries [5]. This could be an underestimation [6].
Schizophrenia is characterized by symptoms that may include delusions, hallucinations, catatonia, negative symptoms, and disorganized speech or behavior. Genetic pre-disposition, pregnancy and its complications are said to be some of the risk factors, while viral infections and subsequent autoimmune reactions are causative factors [7].

Trace elements (TE) are suspected to be causative agents in the development of schizophrenia although the mechanism is poorly understood [8]. $\mathrm{Cu}$, a component of several enzymes linked to dopamine synthesis, may play a role in schizophrenia by exacerbating or perpetuating dopaminergic dysregulation. Furthermore, it is suggested that ceruloplasmin elevation in schizophrenia is specific, and not simply an elevation of plasma coppercontaining oxidative enzymes [9]. Abnormalities in $\mathrm{Cu}$ metabolism have been demonstrated in schizophrenics $[10,11]$. This link is attributed to several metalloenzymes associated with dopamine 
synthesis and regulation [12]. Dopamine and other catecholamines act as important hormones and neurotransmitters of the central and peripheral nervous system and have functions in the brain that control emotions [13, 14] and cognition [15].

$\mathrm{Se}$ is an integral component of glutathion peroxidase (GPx) which protects against reactive oxygen species (ROS). Selenoprotein $R$ and thioredoxin, another selenoprotein, play similar protective roles [16]. Because oxidative stress increases DNA damage, Se deficiency could result in a higher mutation rate, increasing the likelihood that the sequence of a schizophrenia-related genetic region will be altered [17-18].

Zinc deficiency in the latter part of gestation impair fetal growth, brain size, total brain cell count, and the period of macroneuronal proliferation [19-20] and neurotransmitter functions. One explanation is attributed to the failure of thymidine incorporation into brain DNA, a decreased rate of protein synthesis and a smaller hippocampus [21]. Low and normal serum zinc levels have been demonstrated in studies with Bangladeshi and Turkish schizophrenics, respectively $[11,22]$.

Lead $\left(\mathrm{Pb}^{2+}\right)$ is a neurotoxicant present in the environment and capable of producing biochemical, anatomical, and neurological changes that altogether produce behavioural changes in human development and the manifestation of schizophrenia later in life. $\mathrm{Pb}$ exposure in the course of development manifests in expressions of increased spontaneous activity, decreased social interaction, and learning deficits presents also in schizophrenics [23].

Lead is a potent antagonist of the $N$-methyl-daspartate (NMDA) receptor (NMDAR). It is the reduced expression of NMDAR that is ideated to be associated with the pathophysiology of the disease [24]. Furthermore, reduced dentate gyrus (DG) neurogenesis has been demonstrated in an animal model using phencyclidine which is an NMDAR antagonist [25].

The biochemical mechanisms of action of $\mathrm{Li}$ appear to be extraordinarily complex, multifactorial and strongly intercorrelated with the functions of other elements, drugs, enzymes, hormones, vitamins, growth and transforming factors [26]. Rats on a Lideficient diet demonstrated suppressed liver-press avoidance behavior [27]. Furthermore, rats on a $\mathrm{Li}$ deficient diet exhibited diminished wheel-running activity, decreased response to handling and lower aggression in social interactions [28]. Evidence linking low Li intake with altered behavior and aggressiveness in humans has been reported [29]. Genetic factors have also been implicated in the metabolism of Li. The precise therapeutic mechanism of $\mathrm{Li}$ remains unknown, but may involve the circadian clock. Molecular components of the circadian clock are known to be Li sensitive [30-34]. Li also inhibits glycogen synthase kinase $3 \beta($ GSK3 $\beta)$ [33], which in turn regulates protein turnover and stability in the clock network by phosphorylating target proteins, thereby modulating circadian rhythms [34].

The aim of the study therefore was to determine deficiency, toxicity or dysmetabolism of $\mathrm{Cu}$, $\mathrm{Se}, \mathrm{Zn}, \mathrm{Pb}$ and $\mathrm{Li}$ in Ghanaian schizophrenic patients in Accra since no such data exist.

\section{Subjects and Method}

This was a case-control study. Ethics approval was obtained from the Ghana Health Service (GHS-ERC: 16/05/12) and the University of Ghana School of Allied Health Sciences (SAHSET./10285645/AA/26A/2012-2013). A total of 81 clinically diagnosed psychiatric patients made up of 42 males and 39 females, from the Pantang Hospital (Accra) and 25 apparently mentally healthy agematched and sex-matched controls (13 males and 12 females) were recruited for the study in July 2013. Simple random sampling was used to recruit subjects. Psychiatric patients should have been on admission for not less than five (5) years.

\section{Treatment of Glassware}

All glassware and tubes were soaked in $10 \%$ (w/v) $\mathrm{HNO}_{3}$ (Fluka, Germany) overnight and then rinsed with deionized water.

\section{Digestion Protocol for Sample}

Digestion of samples was done according to standard trace element analysis protocols using milestone microwave labstation ETHOS 900 (INSTR: MLS-1200 MEGA) programme (Table 1).

Table 1: Microwave digestion programme.

\begin{tabular}{|c|c|c|c|c|c|}
\hline Step & Time & Power & Pressure & $\begin{array}{l}\text { Temp }{ }^{\circ} \mathrm{C} \\
\text { [1] }\end{array}$ & $\begin{array}{l}\text { Temp }{ }^{\circ} \mathrm{C} \\
\text { [2] }\end{array}$ \\
\hline 1 & 00:02:00 & 250 & 100 & 400 & 500 \\
\hline 2 & 00:02:00 & 0 & 100 & 400 & 500 \\
\hline 3 & 00:06:00 & 250 & 100 & 400 & 500 \\
\hline 4 & 00:05:00 & 400 & 100 & 400 & 500 \\
\hline & 00:05:00 & 650 & 100 & 400 & 500 \\
\hline \multicolumn{2}{|c|}{ Vent:00:05:00 } & \multicolumn{2}{|c|}{ Rotorctrl on } & Twist on & \\
\hline
\end{tabular}

After cooling, the digestate was then transferred into a volumetric flask and diluted to $20 \mathrm{~mL}$ with deionized water. The diluted digestate was assayed for the level of $\mathrm{Cu}, \mathrm{Se}, \mathrm{Zn}, \mathrm{Pb}$ and $\mathrm{Li}$ using VARIAN AA 240FS-Atomic Absorption Spectrometer (Kungsbacka, Sweden) along with standards of high purity metals from Teknolab AS (Kungsbacka, Sweden) and reference material Seronom ${ }^{\text {TM }}$ Trace Elements Serum L-1, L-2 (Billingstad, Norway) under conditions in Table 2. Blank samples were also digested and analyzed along with the samples. 
Table 2: Analytical conditions of elements.

\begin{tabular}{llllll}
\hline Element & $\begin{array}{l}\text { Wavelength } \\
\mathbf{n m}\end{array}$ & $\begin{array}{l}\text { Lamp } \\
\text { Current } \\
\mathbf{m A}\end{array}$ & $\begin{array}{l}\text { Slit } \\
\text { Width }\end{array}$ & Fuel & Support \\
$\mathrm{ne}$ & 196.0 & 10 & 1.0 & ACETYLENE & AIR \\
$\mathbf{P b}$ & 217.0 & 5 & 1.0 & ACETYLENE & AIR \\
$\mathbf{C u}$ & 324.7 & 4 & 0.5 & ACETYLENE & AIR \\
$\mathrm{Li}$ & 670.8 & 5 & 1.0 & ACETYLENE & AIR \\
\hline \multicolumn{2}{l}{ (VARIAN, 1989) } & & & &
\end{tabular}

\section{Quality Assurance and Control Measures}

The method detection limit was calculated as the mean of the blank concentration and three times the standard deviation. Values below detection limit of the instrument were replaced by the method detection limit divided by the square root of two. Contro samples and standards were measured. Linearity was assessed by the calibration curve of all the elements measured. Replicate measurement for each sample was taken to ensure precision.

\section{Statistical Analysis}

The statistical analyses of the data was done using SPSS (Statistical Package for Social Sciences) version 16.0. Means \pm standard deviation were determined for quantitative variables. Chi-square was used for categorical data and independent t-test for demographic data. Comparison of $\mathrm{Cu}$, Se and $\mathrm{Zn}$ levels between the psychiatric patients and the control group were performed with unpaired $t$-test. Abnormally distributed data $(\mathrm{Pb})$ was analyzed with Wilcoxon-Mann/Whitney test. Pearson's correlation was used to test the relationship between the trace elements, gender and age. $P$-values $\leq 0.05$ were considered statistically significant.

\section{Results}

\section{Demographic Data}

A total of 81 clinically diagnosed psychiatric patients (20-57 years), made up of 42 males (51.2\%) and 39 females (48.1), and 25 apparently mentally healthy controls (13 males and 12 females) (23-51 yrs) were recruited for the study. The mean age was $32.32 \pm 0.84$ yrs for cases and $33.64 \pm 1.64$ years for controls. Cases were found to be on haloperidol $(0.5$ $\mathrm{mg}-3 \mathrm{mg}$ ).

\section{Trace Elements Concentrations}

The mean $\mathrm{Cu}, \mathrm{Se}, \mathrm{Zn}$ and $\mathrm{Pb}$ levels for the test and control groups were $766 \pm 250 \mu \mathrm{g} / \mathrm{L}, 149 \pm 72$ $\mu \mathrm{g} / \mathrm{L}, 702 \pm 438 \mu \mathrm{g} / \mathrm{L}, 1.38 \pm 0.05 \mu \mathrm{g} / \mathrm{L}$ and $855 \pm 270$ $\mu \mathrm{g} / \mathrm{L}, 108 \pm 61 \mu \mathrm{g} / \mathrm{L}, 1007 \pm 593$ and $0.10 \pm 0.05 \mu \mathrm{g} / \mathrm{L}$, respectively. Graphical representations of $\mathrm{Cu}, \mathrm{Se}, \mathrm{Zn}$, $\mathrm{Pb}$ and $\mathrm{Li}$ concentrations of the subjects are shown in Figure 1, 2, 3, 4 and 5, respectively. Statistical differences found between the psychiatric patients and the controls for the elements $\mathrm{Cu}, \mathrm{Se}, \mathrm{Zn}$ and $\mathrm{Pb}$ were $p=0.168, p=0.009, p=0.028$ and $p=0.001$, respectively (Table 3 ).

Table 3: The levels of trace elements of Schizophrenic patients (cases) and controls.

\begin{tabular}{|c|c|c|c|c|c|}
\hline & \multicolumn{2}{|c|}{ Controls } & \multicolumn{2}{|c|}{ Cases } & \multirow[t]{2}{*}{$p$ values } \\
\hline & $\mathrm{N}$ & Mean & $\mathrm{N}$ & Mean & \\
\hline Copper $(\mu \mathrm{g} / \mathrm{L})^{\mathrm{a}}$ & 25 & $855 \pm 270$ & 81 & $766 \pm 250$ & 0.168 \\
\hline Selenium $(\mu \mathrm{g} / \mathrm{L})^{\mathrm{D}}$ & 25 & $108 \pm 61$ & 81 & $149 \pm 72$ & 0.009 \\
\hline Zinc $(\mu \mathrm{g} / \mathrm{L})^{\mathrm{c}}$ & 25 & $1007 \pm 593$ & 81 & $702 \pm 438$ & 0.028 \\
\hline Lead $(\mu \mathrm{g} / \mathrm{L})^{\mathrm{d}}$ & 25 & $0.10 \pm 0.05$ & 81 & $1.38 \pm 0.05$ & 0.001 \\
\hline Lithium $(\mu \mathrm{g} / \mathrm{L})$ & 25 & $\mathrm{BDL}$ & 81 & $4077 \pm 2567$ & \\
\hline
\end{tabular}

Li levels could be detected in only 16 samples of the test group, giving a mean value of $4077 \pm 2567$ $\mu \mathrm{g} / \mathrm{L}$. The controls were also below the detection limit of the equipment $(<0.02 \mu \mathrm{g} / \mathrm{L})$. Therefore, only descriptive statistics was done for Li (Table 3). Values that could not be detected by the FAAS were replaced with the method detection limit (MDL) which is:

$\mathrm{MDL}=$ Mean of Blank Concentration * ${ }^{*} \mathrm{SD}$,

Non Detected Values $=\mathrm{MDL} / \sqrt{ } 2$

Table 4: The levels of trace elements in Psychiatric patients and controls according to gender.

\begin{tabular}{|c|c|c|c|c|c|c|}
\hline & & $\begin{array}{c}\mathrm{Cu} \\
(\mu \mathrm{g} / \mathrm{L})\end{array}$ & $\begin{array}{c}\mathrm{Se} \\
(\mu \mathrm{g} / \mathrm{L})\end{array}$ & $\begin{array}{c}\mathrm{Zn} \\
(\mu \mathrm{g} / \mathrm{L})\end{array}$ & $\begin{array}{c}\mathrm{Pb} \\
(\mu \mathrm{g} / \mathrm{L})\end{array}$ & $\begin{array}{c}\mathbf{L i} \\
(\mu \mathrm{g} / \mathrm{L})\end{array}$ \\
\hline \multirow[t]{2}{*}{ Cases } & Males & $775 \pm 270$ & $124 \pm 52$ & $639 \pm 439$ & $0.48 \pm 0.28$ & $3233 \pm 1038$ \\
\hline & Females & $757 \pm 230$ & $181 \pm 82$ & $774 \pm 433$ & $1.63 \pm 0.75$ & $3549 \pm 1341$ \\
\hline \multirow[t]{2}{*}{ Controls } & Males & $799 \pm 320$ & $113 \pm 77$ & $945 \pm 539$ & $0.12 \pm 0.05$ & BDL \\
\hline & Females & $916 \pm 200$ & $102 \pm 39$ & $1064 \pm 609$ & $0.08 \pm 0.04$ & BDL \\
\hline
\end{tabular}

Female values were higher in all trace elements except for $\mathrm{Cu}$. However, for the control group, copper was higher in males (Table 4). Furthermore, females had very high Se (181 \pm 82 $\mu \mathrm{g} / \mathrm{L})$ compared to males $(124 \pm 52 \mu \mathrm{g} / \mathrm{L}) \quad(\mathrm{p}=0.05)$ and low $\mathrm{Zn}(639 \pm 439 \mu \mathrm{g} / \mathrm{L})$ compared to females $(774 \pm 433 \mu \mathrm{g} / \mathrm{L})(\mathrm{p}>0.05)$ (Table 4).

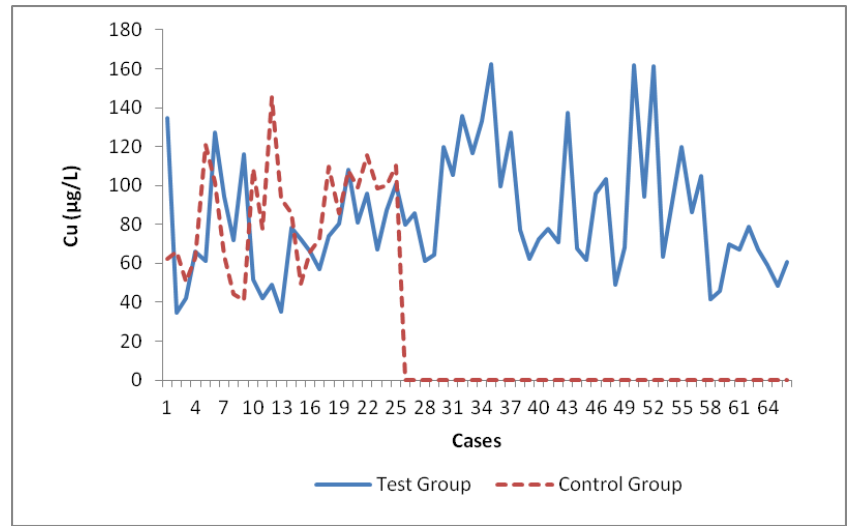

Figure 1: Different levels of copper $(\mathrm{Cu})$ in the subjects. The test group showed significantly higher Cu levels than the controls.

There was no correlation between the levels of trace elements and the age or gender of the participants. A positive correlation existed between $\mathrm{Li}$ and $\mathrm{Pb}(\mathrm{p}=0.023)$ (Table 4). 


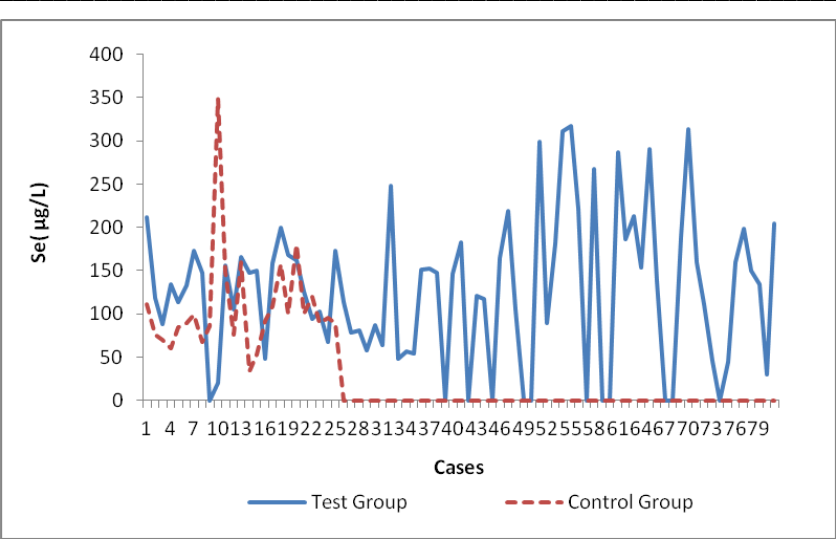

Figure 2: Selenium (Se) levels in all the subjects. Significantly higher levels were observed in the test group compared to the controls.

\section{Discussion}

Mean $\mathrm{Cu}$ level of the Case group was 766 $\mu \mathrm{g} / \mathrm{L}$ and the control group was $855 \mu \mathrm{g} / \mathrm{L}$. Values obtained for the Case group were statistically insignificant compared to the control group. Similarly, in the study of Nechifor et al. [35] no significant $\mathrm{Cu}$ differences were observed between cases and controls. On the contrary, the mean value of $\mathrm{Cu}$ for schizophrenic cases was $720 \mu \mathrm{g} / \mathrm{L}$ while that of the Control group was $590 \mu \mathrm{g} / \mathrm{L}$ in another study. Differences were statistically significant [9]. Yanik et al. [11] also reported of similar values; $980 \mu \mathrm{g} / \mathrm{L}$ (Cases) and $760 \mu \mathrm{g} / \mathrm{L}$ (control group) $(\mathrm{p}<0.05)$. However, higher values of $1174 \mu \mathrm{g} / \mathrm{L}$ for Schizophrenic cases and $1056 \mu \mathrm{g} / \mathrm{L}$ for controls with differences that were statistically significant have been reported. Altered levels of trace elements in schizophrenic patients may be a consequence of antipsychotic treatment [10].

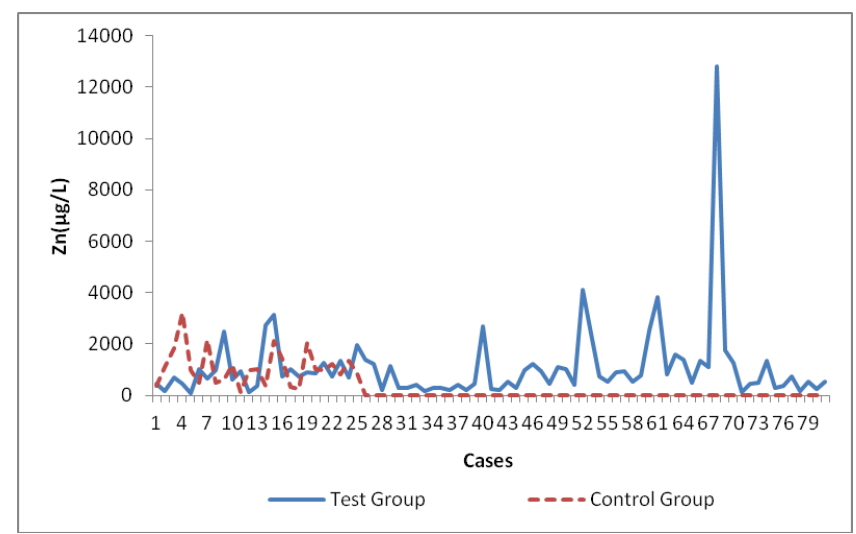

Figure 3: The levels of zinc $(\mathrm{Zn})$ in the test group and the controls $\mathrm{Zn}$ levels were significantly higher in the test group than the control. A high level was observed for case 69 which was complemented by very low selenium levels (Figure 2).

Normal brain functioning depends on the role of the Cu-containing enzyme dopamine -bhydroxylase converting dopamine into norepinephrine. Other enzymes such as lysyl oxidase (responsible for collagen synthesis) or monoamine oxidase $A$ and $B$ (the enzyme that eliminates dopamine) all contain copper. Therefore diminished copper impair these functions. On the contrary excess $\mathrm{Cu}$ will also reduce $\mathrm{Zn}$-thionein and CuZnSOD, and other enzymes required for serotonin secretion as a result of competitive absorption with $\mathrm{Zn}$, resulting in diminished $\mathrm{Zn}$ absorption. These aforementioned antioxidants are relevant in the maintenance of $\mathrm{Cu}-\mathrm{Zn}$ homeostasis and failure to regulate excess $\mathrm{Cu}$ will lead to oxidative stress and damage. Dysmetabolism of these metals as well as disturbances of the dopamine/ norepinephrin pathway have been implicated in schizophrenia [36].

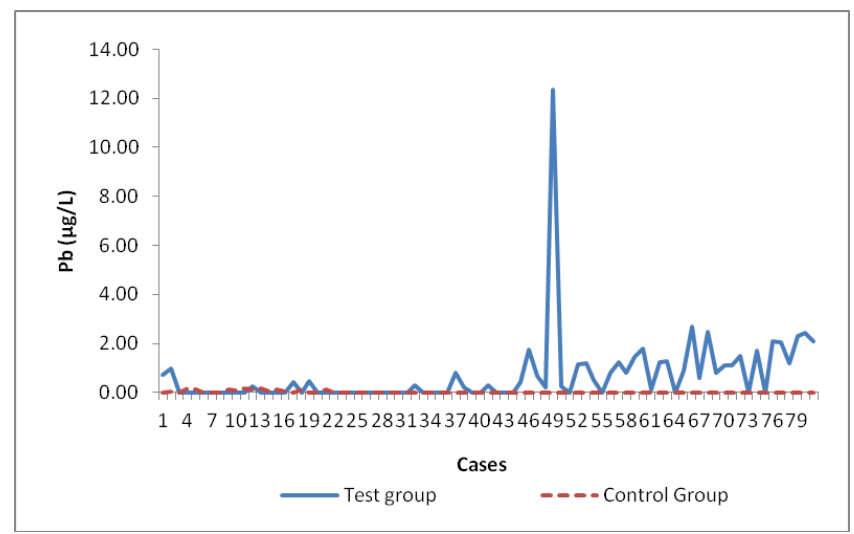

Figure 4: The levels of lead $(\mathrm{Pb})$ in the test group and the controls. $\mathrm{Pb}$ levels were significantly higher in the test group than the control. Case 49 had very high $\mathrm{Pb}$ levels accompanied by very low selenium levels (Figure 2).

Se was $149 \mu \mathrm{g} / \mathrm{L}$ (cases) and $108 \mu \mathrm{g} / \mathrm{L}$ (control). Thus, Se was higher in the Schizophrenic group above the reference interval and statistically significant when compared to the control group ( $p=$ $0.001)$. The mean value obtained for the control group was similar to that obtained in a previous study (123 $\mu \mathrm{g} / \mathrm{L})$ [37]. Significantly similar higher Se levels in schizophrenics were reported by Kharb et al. [38]. In that study Se levels of cases and controls were 134 $\mu \mathrm{g} / \mathrm{L}$ and $101 \mu \mathrm{g} / \mathrm{L}$, respectively.

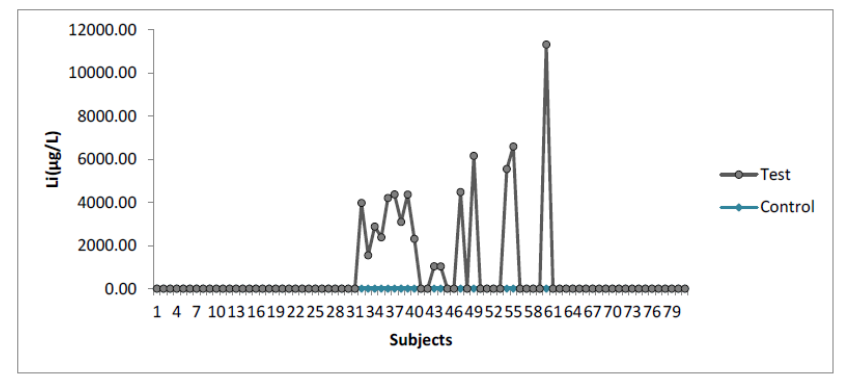

Figure 5: The levels of lithium (Li) in the test group and the controls. Most of the control levels were below the detection limit. However, case 60 showed very high Li levels accompanied by very low selenium levels (Figure 2).

Differences were attributed to geographical locations and soil Se levels. Yanik et al. [11] also 
reported of a higher Se level in Schizophrenics $(71.65$ $\mu \mathrm{g} / \mathrm{L})$ compared to Controls $(69.65 \mu \mathrm{g} / \mathrm{L})$. Differences however, were insignificant. Low blood Se concentrations in schizophrenic patients on clozapine have been reported; $101 \mu \mathrm{g} / \mathrm{L}$ (cases) verses $116 \mu \mathrm{g} / \mathrm{L}$ (control), with differences being significant [39]. That study however, could not attribute the low Se to clozapine.

Some authors have pointed out that the geography of schizophrenia may have possible links with Se and calcium deficiencies [40, 41]. However, it is unknown whether schizophrenics display selenium deficiency prior to diagnosis. Tada et al. [42] for example, discovered elevated selenium in the hair of male but not female patients. In contrast, Alertsen et al. [43] found no difference between the levels of selenium in the serum and blood of Norwegian schizophrenics and controls.

In this study, the mean $\mathrm{Zn}$ level was 1007 $\mu \mathrm{g} / \mathrm{L}$ for the control group compared to $702 \mu \mathrm{g} / \mathrm{L}$ for the case group. Similar low $\mathrm{Zn}$ level was obtained in the schizophrenic group $(600 \mu \mathrm{g} / \mathrm{L})$ in another study [35] compared to $890 \mu \mathrm{g} / \mathrm{L}$ for the control group. In that study differences were significant and treatment raised the $\mathrm{Zn}$ levels appreciably. $\mathrm{Zn}$ plays a very complex role in the brain and $\mathrm{Zn}$ deficiency is postulated in the pathogenesis of schizophrenia [44]. Pfeiffer and llier [45] showed a lower plasma Zn level coupled with excess $\mathrm{Cu}$ in schizophrenic patients and $\mathrm{Zn}$ loss in the hippocampus of schizophrenic patients has also been demonstrated [46]. On the contrary, another study did not observe any significant difference between $\mathrm{Zn}$ levels of cases and controls [11]. In a similar study, serum $\mathrm{Zn}$ was lower among schizophrenic criminals compared to schizophrenic non-criminals $(680 \mu \mathrm{g} / \mathrm{L}$ and $810 \mu \mathrm{g} / \mathrm{L}$, respectively $)$ with significant differences [47]. Thus, low serum Zn in major depression is a sensitive marker of treatment resistance and of the immune/inflammatory response in mental illness [48]. Furthermore, $\mathrm{Zn}$ deficiency exacerbates loss in blood-brain barrier integrity induced by hyperoxia [49].

$\mathrm{Pb}$ levels in the case group and control group were $1.38 \mu \mathrm{g} / \mathrm{L}$ and $0.10 \mu \mathrm{g} / \mathrm{L}$, respectively. Statistically, differences were significant $(p=0.001)$. Furthermore, case 49 (Figure 4), demonstrated very high $\mathrm{Pb}$ levels $(12 \mu \mathrm{g} / \mathrm{L})$, with corresponding low $\mathrm{Cu}$ and Se values (Figure 1 and 2, respectively). Prenatal $\mathrm{Pb}$ exposure and schizophrenia has been argued [50, 51]. The possible neurobiological connection with $\mathrm{Pb}$ exposure could be due to the fact that $N$-methyl-daspartate receptor (NMDAR) may be affected by the antagonistic effect of $\mathrm{Pb}$ on NMDA thereby reducing the function of NMDAR which is involved in the pathophysiology of the disease [52]. Generally, exposure to such insults from the environment and damage or alteration to the developing central nervous system may be associated with schizophrenia and other mental disorders [53-55].
$\mathrm{Li}$ levels in this study were below the detectable limit in all control subjects and majority of the cases. However, very high Li observed in case 60 (Figure 5) corresponded to a very low Se level (Figure 2). Much as Li may act as mood stabilizer, information on its efficacy is inconsistent [56]. Adjunctive Li and anticonvulsants for the treatment of schizophrenia seem to lack the necessary evidence [57]. The dearth of $\mathrm{Li}$ levels of schizophrenic patients is also problematic.

In conclusion, $\mathrm{Se}, \mathrm{Pb}$ and $\mathrm{Li}$ levels were significantly higher in schizophrenic patients compared to controls. $\mathrm{Zn}$ and $\mathrm{Cu}$ levels were significantly lower in the cases than the controls. Female Se levels were extremely high approaching toxic levels while male $\mathrm{Zn}$ levels were extremely low approaching deficiency levels. TE dysmetabolism exist among schizophrenics and monitoring of TE is essential to avoid the adverse effects of metal deficiency and/or overload in tandem with mental disease. To the best of our knowledge this data is the first on schizophrenics and trace elements in Ghana.

\section{References}

1. World Health Organization. World Health Report 2001, Geneva, 2001.

http://www.who.int/whr/2001/media_centre/press_release/en/index. $\mathrm{html}$

2. World Health Organization. Ghana Country Summary, Dept. Of Mental Health and Substance Abuse, 2007. http://www.who.int/mental_health/policy/country/ghana/en/

3. Wittchen HU, Jacobi F. Size and burden of mental disorders in Europe - a critical review and appraisal of 27 studies. Eur Neuropsychopharmacol. 2005; 15: 357-76.

4. Saha S, Chant D, Welham J, McGrath J. A systematic review of the prevalence of schizophrenia. PLoS Med. 2005; 2:e141.

5. Bhugra D. The Global Prevalence of Schizophrenia. PLoS Med. 2005; 2:e151

6. Cohen A. Prognosis for schizophrenia in the Third World: A reevaluation of crosscultural research. Culture Med Psychiatry. 1992; 16: 53-75.

7. Deckmann M, Mamillapalli R, Schechtman L, Shinitzky M. A conformational epitope which detects autoantibodies from schizophrenic patients. Clin Chim Acta. 2002; 322: 91-8.

8. Pfeiffer CC, Bacchi D. Cooper, zinc, manganese, niacin and pridoxine in the schizophrenias. Appl Nutr. 1975; 27: 9-39.

9. Wolf TL, Kotun J, Meador-Woodruff JH. Plasma copper, iron, ceruloplasmin and ferroxidase activity in schizophrenia. Schizophr Res. 2006; 86: 167-71.

10. Herran A. Higher levels of serum copper in schizophrenic patients treated with depot neuroleptics. Psychiatry Res. 2000; 94: 51-58.

11. Yanik M, Kocyigit A, Tutkun H. Plasma manganese, selenium, zinc, copper, and iron concentrations in patients with schizophrenia. Biol Trace Elem Res. 2004; 98: 109-117.

12. Bowman MB, Lewis $M$. The copper hypothesis of schizophrenia: a review. Neurosci Biobehav. 1982; Rev 6: 321-328.

13. Anisman $\mathrm{H}$, Zacharko RM. Behavioral and neurochemical consequences associated with stressors. Ann N Y Acad Sci. 1986; 467: 205-225.

14. David J, Brooks PP. Imaging in Parkinson's disease: The role of monoamines in behavior. Biol Psychiatry. 2006; 59: 908-918.

15. Assadi SM, Yücel M, Pantelis C. Dopamine modulates neural 
networks involved in effort-based decision-making. Neurosci Biobehav Rev. 2009; 33: 383-393.

16. Schweizer and Schomburg. Selinium, selinoproteins and brain function. In D. Hatfield, M Berry and V. Gladysshev (eds). Selinium: Its molecular Biology and Role in Human Health. New York: Springer US, 2006: p. 233-248.

17. Xiang N, Zhoa R, Song G, Zhong W. Selenite reactivates silenced genes by modifying DNA methylation and histones in prostate cancer cells. Carcinogenesis. 2008; 29: $2175-2181$.

18. Uthus E, Ross S, Davis C. Different effects of dietary selenium (Se) and folate metabolism in liver and colon of rats. Biol Trace Elem Res. 2006; 109: 201-214.

19. Pfeiffer CC, Braveman ER. Zinc, brain and behavior. Biol Psychiatry. 1982; 17: 513-532.

20. Sandstead HH. Zinc: essentiality for brain development and function. Nutr Rev. 1998; 43(5): 130-137.

21. Fosmire GJ, Al-Ubaidi $Y$, Sandstead $H H$. Some effects of postnatal zinc deficiency on developing rat brain. Pediatr Res. 1975; 9: 89

22. Rahman A, Azad MA, Hossain I, Qusar MM, Bari W, Begum F, Huq SM, Hasnat A. Zinc, manganese, calcium, copper, and cadmium level in scalp hair samples of schizophrenic patients. Bio Trace Elem Res. 2009; 127(2): 102-8.

23. Moreira EG, Vassilieff I, Vassilieff VS. Developmental lead exposure: behavioral alterations in the short and long term. Neurotoxicol Teratol. 2001; 23(5): 489-95

24. Guilarte TR. Prenatal lead exposure and schizophrenia: further evidence and more neurobiological connections. Environ Health Perspect. 2009; 117(5): A190-1.

25. Maeda K, Sugino H, Hirose T, Kitagawa H, Nagai T, Mizoguchi $\mathrm{H}$, Takuma $\mathrm{K}$, Yamada $\mathrm{K}$. Clozapine prevents a decrease in neurogenesis in mice repeatedly treated with phencyclidine. J Pharmacol Sci. 2007; 103: 299-308

26. Schrauzer GN. Lithium: Occurrence, dietary intakes, nutritiona essentiality. J Am Coll Nutr. 2002; 21 (1): 14-21.

27. Ono T, Wada O. Effect of lithium deficient diet on avoidance behavior of animals and a discussion of the essentiality of lithium. Biomed Res Trace Elem. 1991; 12: 264-265.

28. Klemfuss $H$, Schrauzer GN. Effects of nutritional lithium deficiency on behavior in rats. Biol Trace Elem Res. 1995; 48: 131 139.

29. Dawson EB. The relationship of tap water and physiologica levels of lithium to mental hospital admission and homicide in Texas. In: Schrauzer GN, Klippel KF (eds) Lithium in Biology and Medicine, Weinheim, VCH Verlag, 1991: p 171-187.

30. Kripke DF, Wyborney VG. Lithium slows rat circadian activity rhythms. Life Sci. 1980; 26: 1319-1321.

31. Welsh DK, Moore-Ede MC. Lithium lengthens circadian period in a diurnal primate, Saimiri sciureus. Biol Psychiatry. 1990; 28:117 126

32. Abe M, Herzog ED, Block GD. Lithium lengthens the circadian period of individual suprachiasmatic nucleus neurons. Neuroreport. 2000; 11: 3261-3264

33. Klein PS, Melton DA. A molecular mechanism for the effect of lithium on development. Proc Natl Acad Sci USA. 1996; 93: 8455 8459.

34. Yin L, Wang J, Klein PS, Lazar MA. Nuclear receptor Reverbalpha is a critical lithium-sensitive component of the circadian clock. Science. 2006; 311: 1002-1005.

35. Nechifor M, Vaideanu C, Palamaru L, Mindreci I. The influence of some antipsychotics on erythrocyte magnesium and plasma magnesium, calcium, copper and zinc in patients with paranoid schizophrenia. J Am Coll Nutr. 23 2004; 5: 549S- 551S.

36. Johnson S. Micronutrient accumulation and depletion in schizophrenia, epilepsy, autism and Parkinson's disease? Med Hypotheses. 2001; 56: 641-645.

37. Asare GA, Osae' S, Nortey' ENN, Yambire' FK, Amedonu E,
Doku D, Annan Y. Evaluation of serum Metallothionein-1, Selenium Zinc, and Copper in Ghanaian Diabetes Mellitus type 2 Patients. Int J Diabetes Dev Ctries. 2013; DOI 10.1007/S13410-013-0111-9.

38. Kharb S, Sharma A, Vohra AK, Yadav S, Singh I. Selenium levels in patients with schizophrenia. J Med Lab Diag. 2010; 1: 1516.

39. Vaddadi KS, Soosai E, Vaddadi G. Low blood selenium concentrations in schizophrenic patients on clozapine. $\mathrm{Br} \mathrm{J}$ Clin Pharmacol. 2002; 55: 307-309.

40. Foster HD. The geography of schizophrenia: possible links with selenium and calcium deficiencies, inadequate exposure to sunlight and industrialization. J Orthomol Med. 1988; 3: 135-140.

41. Brown Jr. JS, Foster HD. Schizophrenia: An update of the selenium deficiency hypothesis. J Orthomol Med. 1996; 11 (4): 211 222.

42. Tada K, Nogami $\mathrm{Y}$, Nagashima $\mathrm{M}$, Nagase $\mathrm{T}$, Ishiwata $\mathrm{H}$, Motegi $\mathrm{Y}$, Ikeda M. Trace elements in the hair of schizophrenics. Biol Psychiatry. 1986; 21: 325-328

43. Alertsen AR, Aukrust A, Skaug OE. Selenium concentrations in blood and serum from patients with mental diseases. Acta Psychiatr Scan. 1986; 74(2): 217-9.

44. Andrews RC. Unification of the findings in schizophrenia by reference to the effects of gestational zinc deficiency. Med Hypotheses. 1990; 31: 141-153.

45. Pfeiffer CC, Ilier U. A study of zinc deficiency and copper excess in the schizophrenia. Intl Rev Neurobiol. 1972; (Suppl 1) 141-165

46. Adams CE, De Masters BK, Freedman R. Regional zinc staining in post-mortem hippocampus from schizophrenic patients. Schizophr Res. 1995; 18: 71-77.

47. Tokdemir M, Polat SA, Acik Y, Gursu F, Cikim G, Deniz O Blood zinc and copper concentrations in criminal and noncriminal schizophrenic men. Arch of Andr. 2003; 49 (5): 365-8.

48. Maes $M$, Vandoolaeghe $E$, Neels $H$, Demedts $P$, Wauters A, Meltzer HY, Altamura C, Desnyder R. Lower serum zinc in major depression is a sensitive marker of treatment resistance and of the immune/inflammatory response in that illness. Biol Psychiatry. 1997; 42(5): 349-58.

49. Noseworthy MD, Bray TM. Zinc Deficiency Exacerbates Loss in Blood-Brain Barrier Integrity Induced by Hyperoxia Measured by Dynamic MRI. Proc Soc Exp Biol Med. 2008; 223(2): 175 - 182.

50. Opler MGA, Brown AS, Graziano J, Desai M, Zheng W, Schaefer C, Factor-Litvak P, Susser ES. Prenatal lead exposure, סaminolevulinic acid, and schizophrenia. Environ Health Perspect. 2004; 112: 548-552

51. Opler MGA, Buka SL, Groeger J, McKeague I, Wei C, FactorLitvak P, Bresnahan M, Graziano J, Goldstein JM, Seidman LJ, Brown AS, Susser ES. Prenatal exposure to lead, $\delta$ aminolevulinic acid, and schizophrenia: further evidence. Environ Health Perspect. 2008; 116:1586-1590.

52. Guilarte TR. Prenatal Lead Exposure and Schizophrenia: A Plausible Neurobiologic Connection. Environ Health Perspect. 2004; 112 (13): A742

53. Guilarte TR, Opler M, Pletnikov M. Is lead exposure in early life an environmental risk factor for Schizophrenia? Neurobiological connections and testable hypotheses. Neurotox. 2012; 33(3): 560 74.

54. Murray RM, O'Callaghan E, Castle DJ, Lewis SW. A neurodevelopmental approach to the classification of schizophrenia. Schizophr Bull. 1992; 18: 319-32.

55. Weinberger DR. From neuropathology to neurodevelopment. Lancet. 1995; 346: 552-7.

56. Leucht S, Kissling W, McGrath J. Lithium for schizophrenia revisited: a systematic review and meta-analysis of randomized controlled trials. J Clin Psychiatry. 2004; 65: 177-86.

57. Citrome L. Adjunctive lithium and anticonvulsants for the treatment of schizophrenia: what is the evidence? Expert Rev Neurother. 2009; 9(1): 55-71. 